\title{
Applying IFRS9 with Sukuk by IFRS's Compliant Firms
}

\begin{tabular}{lr}
\multicolumn{2}{c}{ Amer Morshed $^{*}$} \\
\hline Received: 07.10 .2020 & Accepted: 21.11.2020 \\
DOI: $10.25272 /$ ijisef.806932 & Type: Research Article
\end{tabular}

\section{Abstract}

This paper explores the applying of the IFRS 9 by the IFRS's compliant firms with Sukuk, concentrating on the problems of Sukuk classification and using the expected credit loss model. Employing the methodology of three stages; started through a written survey with listed firms financial managers then semi-structured interviews language with Islamic accounting and IFRS's experts. Finally, a questionnaire distributed to external auditors. The article concluded; the IFRS's compliant firms could apply the IFRS9 with Sukuk with considering some Islamic rules related to the Sukuk.

The article gives a practical guide to deal with Sukuk under IFRS9. Instructions were suggested to classify and measure the Sukuk. listed firms shall justify that treatment according to the IFRS's conceptual framework. Additionally, using the equity methods as IAS 28 and classifying as financial assets by fair value through profit or loss. Debt-based Sukuk are classified only under amortised cost since they are not tradable. The listed firms should apply the ECLM on Debt-based Sukuk only, and by using other prevailed factor than the interest rate when involving the expected credit loss.providing solutions to the mentioned problems will increase the willingness of the IFRS's compliant firms to invest in Sukuk and advance the Sukuk market.

Keywords: Sukuk, IFRS 9, Financial assets classification, Expected credit loss model, Listed firms in Jordan.

Jel Codes: M41

\footnotetext{
* PhD Candidate in Accounting, University of Sopron. amer.morshed@phd.uni-sopron.hu. ORCID: 0000-0002-97565854
} 


\section{Introduction}

Islamic financial organisations and institutions attempted to issue a financial instrument based on Shariah's rules, in the direction of promoting the Islamic financial market and facilitating the operation of the Islamic banking sector. These efforts reached out issuing investment tools called Sukuk as certificates of equivalent value (Hasan, Ahmad, and Parveen 2019). These certificates are representing undivided shares in ownership of assets, usufruct, and services. Theses Sukuk can be a possession of the assets of particular projects or specific investment venture, after receiving the value of the Sukuk, the closing of subscription and the employment of funds received for the purpose for which the Sukuk were issued (Ahmad 2016). As Hossain et al. (2020) an argument has arisen related to the sukuk function centred on that the similarity of sukuk with bonds. Studies like (Safari and Ariff, 2013; Ahmed et al., 2015) expressed that the Sukuk even it seems doing the same bond work but it different. This opinion came from sukuk are comprised of various contacts which are completely diverse from the components of bonds. On the other side; Fathurahman and Fitriati (2013); Godlewski et al. (2013); Siswantoro (2018); Bhuiyan et al. (2019) indicated an only petty distinction between sukuk and bonds in the function; that caused by Sukuk have fixed-term maturity and a contractual profit rate. This argument directs to several accounting treatments for the Sukuk. The Accounting and Auditing Organization for Islamic Financial Institutions AAOIFI issued two accounting standards in 2019; FAS 33 - Investment in sukuk, shares and similar instruments and FAS 34 - Financial reporting for Sukuk-holder (Accounting and Auditing Organization for Islamic Financial Institutions 2020). Indonesia issued its accounting standards for Sukuk, SFAS No. 110, by the Indonesian Institute of Accountants (Siswantoro 2018). In Malaysia; studies discussed the acceptance of applying the IFRS's ith Islamic financial products as(Mohammed et al. 2019); moreover, Shafii and Abdul Rahman (2016) focused on the accounting treatment of Sukuk under the IFRS9 considering the instructions of Bank Negara Malaysia and Islamic Financial Services Act. Jordan introduced the Islamic finance in the financial market at the end of 1970s. Recently, four Islamic banks are working, these banks had been obliged by the central bank of Jourdan to adopt the AAOIFI accounting standards. On the other hand, the listed companies have to publish their financial reports in compliance with IFRS's (Ahmad 2018). A survey was done by the researcher to investigate the willingness and the problems of Sukuk investment between the listed companies in Jordan. The survey showed that a significant number of these firms have the desire to invest in Sukuk. This willingness is caused by avoiding interest (usury) and increase investment diversification. The listed companies face the problem of being compliant under IFRS when investing in Sukuk. Although the application of IFRS9 with Sukuk is possible in Malaysia, listed firms in Jordan can not use the applied instruction in Malaysia since two reasons 1- different Islamic jurisdiction school (Hikmany and Oseni, 2016) 2- the rules of Bank Negara Malaysia are valid in Malaysia only. The survey summarized the problem in two themes; Sukuk classification and measuring under IFRS9 and 
avoiding interest with Sukuk when applying the expected credit loss model. This study aims the find solution for the themed problems, which jordans listed firms face when investing in sukuk, regarding the jurisdiction differences and the external audit acceptance. This aim gains its value from the predicted growth in the Sukuk market when the mentioned problem be resolved(Smaoui and Khawaja 2017). The next section discusses the literature review following by the methodology. Section four is data and results. The last two sections are discussion and implication then summary and conclusion.

\section{Literature Review}

\subsection{Sukuk Classification}

According to Huian (2012); Shafii and Abdul Rahman (2016); Mohamad and Hamed (2017); Gornjak (2017) the IFRS9 introduced the business model for classifying and measuring the financial assets. Measuring at amortised cost when the assets are held within a business model aim to keep assets to receive future cash inflows, and the payments of principal and the interest were determined to flow on specified dates by the assets contract. When the entity held any financial assets for trading, the assets are measured at fair value through profit or loss. Financial assets are measured at fair value through other comprehensive income if they are held in a business model aim to both collecting cash flows and trading. Equity instruments are measured at fair value, with value changes recognised in profit or loss. Excluding those equity investments for which the entity has selected to present value changes in 'other comprehensive income.

On the other hand, Hidayat (2013) ; Ahmed et al.(2015); Biancone and Shakhatreh (2016); Smaoui and Khawaja (2017); Alswaidan et al. (2017); Borhan and Ahmad (2018); Hasan et al. (2019) contributed in the interpretation of the AAOIFI FAS 34 - Financial reporting for Sukuk-holder . The standard classifies the Sukuk to two categories ;

Business Sukuk, which structured on an underlying business contract. It can be a single contract as an investment; Musharakah and Mudarabah, or trade; Murabahah and Salam, or a compounded.

Sukuk were structured on Murabahah and Salam contracts are debt-based Sukuk(selling based Sukuk). The revenue of the holder is contractual and depending on the credit risk of the issuer, and this Sukuk are not tradeable. Sukuk were structured on partnership contracts, Musharakah and Mudarabah, are equity-based Sukuk. The holders contribute to investing in a project and their revenue is volatile depending on the performance of the project.

The recognition and measuring of these Sukuk are according to the related Islamic accounting standard for each contract which comprises the Sukuk.

Not business (Assets) Sukuk, which is any Sukuk which is not a business Sukuk. 
Sukuk Ijara are a common example of this type of Sukuk. The issuer still has the legal ownership of the underlying assets and transfers only the usufruct of the asset to Sukuk holders, and Sukuk holders have the recourse to the issuer and their revenue is contractual.

However, the initial recognition at a cost which is the consideration paid or payable for the same. After initial recognition, the underlying assets shall be measured at fair value at each reporting date. When the fair value cannot reasonably be determined, measuring is at carrying amount calculated at cost or amortised cost. Fair valuation of the assets, on an individual or collective basis, shall be determined with suitable frequency ensuring that the decision making of the stakeholders might not be affected by the obsolescence of information.

It is presumed that the FAS 34 implements different methodology of classification. This methodology relay on the sukuk structure not on the business model as IFRS 9. This variation means that the AAOIFI did not consider the harmonization effort by ACCA and KPMG in 2010 (Gharbi 2016; Ahmed et al. 2016). Moreover, this distinction made using FAS 34 as a reference by the listed firms in Jordan when dealing with Sukuk useless. This opinion is supported by survey proceed [...] I studied FAS 34 to use it as a guide for the Sukuk accounting under IFRS 9. I found it inconspicuous and not connected with IFRS 9. Moreover, it wants me to be expert in Islamic accounting and finance. The last sentence is a response to the business sukuk accounting since the standard required the accounting treatment for this sukuk to be according to the related Islamic accounting standard for each contract that comprises the Sukuk.

On the other hand, concerning the Shariah Advisory Council (SAC) of Bank Negara Malaysia and the Asian-Oceanian Standard Setters Group (AOSSG) instructions Shafii and Abdul Rahman (2016) provided a proposal to classify and measure the Sukuk by a treatment that simulates the business model under IFRS 9. Unfortunately listed firms in Jordan can not use the functional instruction in Malaysia since two reasons 1- different Islamic jurisdiction school (Hikmany and Oseni 2016) 2- the rules of Bank Negara Malaysia are valid in Malaysia only.

Accordingly, the question "what is the accounting treatment, classification and measuring, of Sukuk that the listed firms in Jordan should apply under IFRS's?" becomes essential.

\subsection{The Expected Credit Loss Model (ECLM)}

Gornjak (2017) mentioned that the IFRS9 introduced the expected credit loss model (ECLM) as a unified model to run the impairment of financial assets held under amortization cost. This model produces tangible changes in accounting policies, which adapts future losses; moreover, stakeholders have a vision into an instrument with increase the credit risk. Novotny-Farkas (2016) said the recent recognition of credit losses would diminish the accumulated of loss continuations and the overemphasis of regulatory capital. Furthermore, protracted disclosure requirements are possible to contribute to more effective market discipline. Through these channels, IFRS 9 
improve financial stability. Gomaa et al. (2018) realised that the FASB requires the current judgment of all cash flows not assumed to be settled by an entity, that includes all financial instruments at each reporting date.

According to IFRS's reports the general model for impairment based on fluctuations in credit quality since initial recognition in three steps(IFRSin-depth-expected-credit-losses.pdf 2018; Schutte et al.2020):

The first Stage involves financial instruments that do not have a meaningful increase in credit risk after the initial recognition, or that has low credit risk at the reporting date. For these assets, twelve -months expected credit losses are recognised, and interest revenue is calculated on the gross carrying amount of the asset; considering that is, without deduction for credit allowance. Twelve -months are the expected credit losses that result from default events that are apparently within twelve -months after the reporting date. It is not the predicted cash shortfalls over the 12 months but the entire credit loss on an asset-weighted by the probability that the loss will happen in the following twelve -months.

The second Step involves financial instruments that have a significant increase in credit risk after the initial recognition, but there is no actual indication of an impairment unless they have low credit risk at the reporting date. Accordingly; the lifetime of expected credit losses of these assets are recognised, and the calculation of the interest will be on the gross carrying amount of the asset. The period of anticipated credit losses are the expected credit losses that occur from all possible default cases of the whole assumed life of the financial instrument. Expected credit losses are the weighted average credit losses with the probability of default as the weight.

The third Stage includes financial assets that have objective evidence of impairment at the reporting date. For these assets, the entity recognises the lifetime of expected credit losses, and interest revenue is calculated on the net carrying amount.

On the other hand, the expected credit loss has been not mentioned in AAOIFI FAS 34. Nevertheless, the AAOIFI issued FAS 30 - Impairment and Credit Losses and Onerous Commitments in 2017 FAS 30 provides an expected credit loss approach that simulates the ECLM of IFRS 9. This approach is only for receivable and off-balance sheet exposures without mentioning the Sukuk since FAS 34 required the accounting treatment for business sukuk to be according to the related Islamic accounting standard for each contract that comprises the Sukuk. Accordingly, there is no clear reference provided by the AAOIFI to the IFRS's compliant institution for implementing the ECLM with Sukuk. This situation opened the discussion for the directions to how to apply the ECLM with Sukuk by the IFRS's compliant institution.

Shafii and Abdul Rahman (2016) found that Muslim jurists have different views on the use of interest rates as a criterion for determining the discount rate though many agree that interest is 
just a reference rate. Therefore, the use of interest rate as a criterion is a problem from an Islamic perspective, although the discount is acceptable in Islam and desirable because it allows enhancing the efficiency and use of investment. Misman and Ahmad (2011) said, Malaysia adapts the impairment based on discount rates. The Malaysian argument is that discount rates used in the Impairment are only for calculation, and it is not for crediting interest to a debtor. Siswantoro (2018) mentioned that the Islamic Sharia Council in Indonesia has not authorized the use of interest as a discount factor.

Accordingly, the question " how to apply the ECLM with Sukuk by the listed firms in Jordan?" becomes essential.

\section{The Research Methodology and Design}

This paper started with an open written survey about Sukuk investment desire and obstacles. The survey has been written with Arabic then sent by e-mail to the financial managers of listed firms, which have financial transaction with Islamic banks, in Jordan except for banks. When surveys had been replyed, the researcher translated them to English and coded them manually. The surveys' results were connected with the literature review and used as a base for the semistructured interviews of the next step. The next stage, according to the small number of people in Jordan they are awareness of the Islamic finance and the need to an in-depth discussion about the issue, in addition to the literature review as mostly adapted the qualitative methods; for example, Mohammed et al. (2019). Examine the opinions of interviews gathered from semi-structured interviews with two segments of participants. The first group is consisting of eight experts in Islamic accounting (professors of Islamic accounting at Islamic finance departments, financial managers of Islamic banks and five Islamic scholars). The second group is eight International Financial Reporting Standards experts (audit managers and financial accounting professors). All the persons interviewed above are actively involved in the preparation, review and teaching of the financial statements of IFIs, Islamic accounting and IFRS. They can, therefore, provide a rich interpretation of reporting practices. Most of them represent the major financial institutions in the Jordanian banking sector. Those interviewed found a strong desire for Islamic finance and thus produced a fruitful penetration in this current paper. The sample as follow:

Table 1. Research Sample

\begin{tabular}{|l|l|}
\hline Description & Qualifications \\
\hline $\begin{array}{l}\text { Islamic finance researcher, lecturer, and } \\
\text { Islamic accounting expert }\end{array}$ & Full professor in Islamic banking \\
\hline $\begin{array}{l}\text { Islamic finance researcher and lecturer and a } \\
\text { member of Sukuk issuing agency }\end{array}$ & Associate professor in Islamic finance \\
\hline Islamic finance researcher and lecturer & Associate professor in Islamic finance \\
\hline
\end{tabular}




\begin{tabular}{|c|c|}
\hline Islamic finance researcher and lecturer & Associate professor in Islamic finance \\
\hline $\begin{array}{l}\text { An assistant general manager at Islamic } \\
\text { financial institution }\end{array}$ & PhD in Islamic banking, JCPA*, and CIPA** \\
\hline $\begin{array}{l}\text { Financial manager at Islamic financial } \\
\text { institution }\end{array}$ & CIPA \\
\hline $\begin{array}{l}\text { Assistant Financial manager at Islamic } \\
\text { financial institution }\end{array}$ & Master's in finance \\
\hline $\begin{array}{l}\text { Senior Accountant at Islamic financial } \\
\text { institution }\end{array}$ & $\mathrm{CPA}^{* * *}$ and CIPA \\
\hline Shariah scholar & PhD in Islamic commercial law \\
\hline Shariah scholar & PhD in Islamic jurisdiction \\
\hline Shariah scholar & PhD in Islamic jurisdiction \\
\hline $\begin{array}{l}\text { Shariah internal control manager at Islamic } \\
\text { financial institution }\end{array}$ & PhD in Islamic jurisdiction \\
\hline $\begin{array}{l}\text { Shariah internal control manager at Islamic } \\
\text { financial institution }\end{array}$ & PhD in Islamic jurisdiction \\
\hline IFRS's researcher, lecturer, and expert & Full professor in financial accounting \\
\hline IFRS's researcher, lecturer, and expert & Full professor in financial accounting \\
\hline IFRS's researcher, lecturer, and expert & Associate professor in financial accounting \\
\hline Audit partner at big four audit firms & CPA \\
\hline Audit Manager at big four audit firms & $\mathrm{ACCA}^{* * * *}$ \\
\hline Audit Manager at big four audit firms & ACCA \\
\hline Audit Manager at big four audit firms & ACCA \\
\hline Manager at a central bank & Master's in accounting and finance \\
\hline
\end{tabular}

The interviews began with the Islamic accounting experts, in the purpose of providing practical and juristic instructions for Sukuk classification and applying ECLM with sukuk under the IFRS9. When a conflict between the IFRS 9 and Sukuk features has arisen, the researcher conducted the other interviews with the IFRS's experts to reach justified accounting treatments for Sukuk, considering the Sukuk features and be complied with IFRS's. 
Consequently, the semi-structured meetings were envisioned to capture the crucial evidence concerning the research purpose. Semi-structured interviews were held within a reasonably open context; hence, the questions asked were not necessarily prepared in advance only the main question to start the conversation. Numerous questions were automatically asked through the interview, providing elasticity to both the interviewer and the participant to investigate and explain additional details or to consider other relevant points, unlike structured interviews, where all questions are designed and arranged beforehand. The meetings were in the form of a conversation rather than a question-and-answer method. All of the interviews were conducted face to face to consider the face expression and sound of the interviewed. The interviews were in Arabic and were translated into English. They were tape-recorded and then transcribed and were then coded manually by the researcher. The researcher also authenticated that their interviews are strictly confidential, as no one identity will be published. Researchers ended the conversations by asking interviewees whether they had any problems for discussion. The process continued with the analysis of interview transcripts and documentary data using qualitative coding and manual recoding researchers this technique depends on the researcher qualifications of the subject since the researcher has an eleven years' experience in Islamic finance and auditing; additionally, professional certificates in Islamic finance and accounting.

The last step; a questionnaire was built on the semi-structured interviews' result. The researcher sent the questionnaire on Excel form by e-mail to 72 external auditors. The questionnaire aims to support the results of the interview and make them more reliable. When the questionnaire received the researcher analysed them using SPSS.

\section{Data and Results}

The researcher received 37 answered surveys. The answering period was almost three months. The residual financial managers, some had apologized since they do not have the desire to invest in Sukuk, the others with no reply.

Reasons for the Sukuk investment' desire have been concluded from the surveys' answers. The first reason is avoiding interest. Since the most redundant sentence[...] our financing policy is to deal with the Islamic banks only to arise fund, so investing in the bond is rejected. The Islamic alternative for investing is required. The second reason is the investment diversification. The participators replied [...] investing in another tool like Sukuk is attractive. [...] adding Sukuk to the portfolio will improve our investment.

On the other side, obstacles related to the accounting treatments of Sukuk under IFRS9 were coded as follow.

- IFRS9 does not provide detailed accounting treatment for the Sukuk. [...] I did not find any treatment for the Sukuk under IFRS9 
-Difficulties in understanding the Sukuk structure to realize their classification. [...] I trying to understand the Sukuk structure. Yet books set an explanation and the AAOIFI used another methodology in their accounting standards. [...] assets based Sukuk, they are equity investment or financial assets.

- Difficulties in understanding the FAS 34 to use it as a reference. [...] I studied FAS 34 to use it as a guide for the Sukuk accounting under IFRS 9. I found it inconspicuous and not connected with IFRS 9. Moreover, it wants me to be expert in Islamic accounting and finance.

-Apply the ECLM with interest factor on Islamic financial instruments. [...] is there another acceptable factor than the interest rate under IFRS 9, since using the interest rate with Sukuk does not make sense.

The semi-structured interviews of the second stage, which have been built on the surveys' results, aim to reach acceptable clarification that could harmonize the accounting treatment under IFRS 9 with Sukuk and help these firm in the Sukuk investment.

The first main question was started with the Islamic accounting professors: the classification of the Assets based Sukuk, as Sukuk Ijarah, should be under financial assets or equity instrument using IFRS 9 ?

Islamic financial accounting professors insisted on classifying the assets bases Sukuk as an equity instrument. Additionally, they rejected the classification of them under financial assets as participants response.[...] Classify assets based Sukuk as financial assets will produce accounting errors. Other participant said, [...] even they have fixed cash inflow, they are under equity instruments. [...] Sukuk Ijara have a fixed rate, yet they are equity instruments. They clarified the accounting treatments of Sukuk Mushrakah and Mudarabah as equity instruments. [...]Mushrakah and Mudarabah Sukuk it is not an obligation on the issuer to pay a profit, and [...]Sukuk Mushrakah and Mudarabah have a right of the underlying assets. Equity instruments are any contract that evidences a residual interest in the assets of an entity after deducting all of its liabilities ( AAOIFI 2020). During the conversation, two participants mentioned [...] the accounting treatment of Sukuk is not clear since Sukuk have the assets and equity criteria this sentence supports the study problem and justify why the listed IFRS's compliant firms in are worried about the accounting problems when they intend to invest in Sukuk.

The same question was repeated to Islamic banks financial managers in the purpose of realising their real practice. The managers cited [...] the central bank obliged us to classify all Sukuk types as financial assets. While the Islamic banks in Jordan apply the AAOIFI accounting standard, they have to follow the instructions of the central and consider the all Sukuk as financial assets (application instruction of IFRS 9- central Jordan bank 2018) Accordingly, even this situation is related only to Islamic banks in Jordan, that also increases the accounting treatment conflict since it is utterly opposed to the professors' opinion. 
To resolve the opinion conflict of the classification and find reasonable classification guidance for companies, which need to invest in assets based Sukuk and be IFRS's complied, The same question was repeated to External auditors, financial accounting professors, with a clear description of the concept and features of Sukuk.

One participant mentioned the ability of the IFRS's to govern the all financial transaction by referring to the conceptional framework [...] IFRS's mentioned in the conceptional framework, if there is IFRS's does not cover an issue, the company must try to resolve it with proper justification. That means if the firm invests in a complicated type of Sukuk, it can justify its accounting treatment according to the IFRS's conceptual framework and be IFRS's complied. The other option was realised from another conversation for the assets based (Ijara) and equity Sukuk. [...]It can be covered by IAS 28 Investments in Associates and Joint Ventures. When connecting this scenario with the first realisation; it will be an acceptable solution by using the equity method if the investment is more the $25 \%$ of the invested firm (IASB 2018). The other solution classifies the assets based (Ijara) and equity Sukuk as financial assets under fair value through other comprehensive income, as a participant added [...] these Sukuk have volatile cash, it has to be recognized by fair value through profit or loss. Because in the case of irregular cash flow the Sukuk will not match the amortization cost method (Gornjak 2017) this accounting treatment will be similar to equity instruments since in this case the Sukuk will evaluate through fair value, and the expected credit loss model is not applicable.

The second main question was started with Islamic accounting professors. Is there any availability to apply the expected credit loss model, that is included in IFRS 9, on the Sukuk? The researcher explained the concept to the participants as a recognition of a loss provision against the future cash inflow from a loan of a bond, based on the company policies and the market interest rate. The professors mentioned the importance of the expected credit loss model [...] anticipating the loss provision is an effective risk hedging, and it saves the stockholders interest. That means the listed firms should apply this model with Sukuk for the reason of risk hedging and IFRS's compliance. However, the participants agreed to apply this model since they cited [...] Islamic banks use the interest rate to determine the Murabaha markup, and it is for risk hedging not for charge interest. During the conversation, they added [...] to avoid any Islamic rules violation, the company should use another factor than the interest rate. To emphasise the Islamic rules part, the researcher repeated the same question to the Shariah scholars with a clear and detailed clarification of the expected credit loss model. The Shariah scholars did not express sharp objection about applying this model [...] no problem when using another factor than the interest rate. and [...] since it was applied to save the investors interest, it will be suitable. These answers were given after two days since the participators were not well informed about ECLM, and they needed to study the matter. This discussion realises that the companies can apply the expected credit loss model on the Sukuk by using other rates than interest. 
The question was repeated to Islamic banks financial managers in the purpose of realising their real practice. The financial managers mentioned that following the central bank rules by all bank in Jordan is obligatory (application instruction of IFRS 9- central Jordan bank 2018). [...] The central bank rules are to apply IFRS 9 in the Sukuk by. However, they do not make any objection to applying it, [...] there is no problem with the provision possession itself since it will be amended if there are any positive indicators. They added an important note for the accounting treatment "debt-based Sukuk are not tradable and have to be only under amortised cost, so the holders should apply the ECLM with them".

Accordingly; by looking at the results of the first question shows the following. Extract accounting transaction that is only debt-based instruments classified as financial assets because they are not tradable under Islamic finance rules and are measured at amortised cost as conventional bonds. Accordingly, the ECLM applies only to debt-based Sukuk.

The third stage in the finding is the questionnaire. The researcher received 49 questionnaires were filled by the external auditors. The answering period was almost three months. The other auditors did not reply. The questionnaires were analysed using SPSS. Only the mean was considered for the result. The adopted scale is 1 to 4 as highly rejected, rejected, accepted and highly accepted. The clarification of the Sukuk concept and structures was attached to the questionnaire. The question and their related results as the following table;

Table 2. Questionnaire Results

\begin{tabular}{|l|l|}
\hline Question & Mean \\
\hline $\begin{array}{l}\text { Do you agree to use the equity method with assets and equity Sukuk when they } \\
\text { represent more the } 25 \% \text { of the assets or the projects? }\end{array}$ & 3.4 \\
\hline $\begin{array}{l}\text { Do you agree that assets and equity Sukuk should be measured under fair value } \\
\text { through profit or loss? }\end{array}$ & 3.2 \\
\hline $\begin{array}{l}\text { Do you agree that the debt-based Sukuk should be measured by the amortization } \\
\text { cost method? }\end{array}$ & 3.8 \\
\hline Do you agree to use another factor than the interest rate with the ECLM? & 3.5 \\
\hline Do you agree to use the ECLM with the debt-based Sukuk only? & 3.6 \\
\hline
\end{tabular}

\section{Discussion and Implication}

The article reviewed the Sukuk structure and explained the related accounting treatment under the FAS of AAOIFI. On the other hand, explained the financial assets classification under the 
business model and the application of the ECLM. However, Jordan has recognised the IFRS's as unified accounting standards and impose the listed firms to report and prepare their financial information according to the IFRS's, but only the Islamic banks have to apply the AAOIFI standards. This is the opposite of what Siswantoro (2018) mentioned that the Islamic banks in Jordan do not follow the AAOIFI. Therefore, the article pointed out two aspects of what the listed firms in Jordan are aware of reporting the Islamic Sukuk under IFRS9; classification and application of the ECLM. This issue reduces the willingness of these firms to invest in Sukuk; therefore, constrain the improvement of the Sukuk market.

The responses of the surveys revolved on what showed the literature review of the dilemmas faced by the IFRS compliant companies. Interestingly, the evidence shows that the interviewees of the semi-structured interviews placed acceptability of reporting the Sukuk under IFRS9 by the IFRS's compliant firms. Moreover, they provide a non-conservative opinion to Shariah's issues of application the expected credit loss model, as a risk provision on Sukuk. While, the conservative opinion has been expressed against the interest rate as a factor, including directions to use a Shariah's acceptable factor. On the other hand, the impasse of classification has raised. The literature review pointed out a dilemma of the conflict between the importance of the IFRS and the conservative shariah scholars on some problems.

The findings show the classification of the Sukuk under the IFRS 9 is critical since the researcher interviewed the IFRS's experts to find a solution for the classification to be IFRS's complied and Sukuk shariah features considered. The interviewees thoroughly recommend the application of ECLM on Sukuk by the IFRS's compliant firms, and they agreed that the application of the provision itself does not mistake the Islamic part of the Sukuk, and it is essential to the accounting information quality and risk hedging. They commented on the using of the interest rate event it just for risk appraisal and not for the gain interest, which is prohibited by Islamic law; using other Shariah's acceptable factor is preferable. This justification could harmonize another opinion in the literature review as Misman and Ahmad (2011) said, Malaysia adapts the impairment based on discount rates, and they argue that discount rates used in the Impairment are only for calculation. Yet, quite the opposite (Siswantoro 2018) IFRS 9 does not take into account any legitimate considerations since it uses the interest rate as a discount factor, the application of this standard by Islamic banks in Indonesia becomes inappropriate. It shows the need for a particular Islamic accounting standard.

The questionnaires results gave a reasonable assurance for the discussion results of the interviews since the mean of the responses is above 3 and that means more than accepted.

The practical implications of the study are; Firstly, the article suggested an accounting treatment for the Sukuk classification under the IFRS's. The assets based Sukuk can be classified under IFRS's using the equity methods as IAS 28 investments in associates and joint ventures if the 
investment more than $25 \%$ in the same firm or it considered as equity method by the directors as the IAS 28 permit. Moreover, the listed firms shall justify that treatment according to the IFRS's conceptual framework. The other classification option is, according to IFRS 9 as financial assets. That can be by fair value through profit or loss because, in the case of irregular cash flow, the Sukuk will not match the amortization cost method. This accounting treatment will be similar to equity instruments since in this case, the Sukuk will evaluate through fair value and the expected credit loss model is not applicable. Debt-based Sukuk are classified only under amortised cost since they are not tradable. Portfolio can be made for each type of Sukuk (assets based, and debtbased) and apply the suitable business model for each one. Secondly, the evidence from the interviews implies how the application should be, which mentioned the priority to use another prevailed discount rate than the interest if available.

On the other hand, these results of Sukuk classification and measuring are not aligned with the FAS 34 classification of Sukuk as business Sukuk and non-business Sukuk. Meanwhile, the results are convergent with (Shafii and Abdul Rahman 2016) study.

Additionally, the results provide a radical accounting treatment, which is only the debt-based Sukuk classified under financial assets since they are non-tradeable under Islamic finance rules and they are measured by amortised cost method as conventional bonds. Accordingly, the expected loss model applies only to debt-based Sukuk with using another discount factor than interest rate as what (Siswantoro 2018) mentioned, rather than a market interest rate, other rates are considered as rental or leasing (Ijarah) rate using the debt-based structure or a profit-sharing (Mudaraba) using the equity-based structure. This finding will provide a useful guide to how the firms will use the ECLM on Sukuk and be fully IFRS's complied.

\section{Conclusion}

The study exhibited the argument about the Sukuk mechanism if it replaces the bonds or not.

The opinion of Sukuk are different than bonds came from that sukuk are comprised of various contacts which are completely diverse from the components of bonds. While the view that indicated an only petty distinction between sukuk and bonds in the function; that caused by Sukuk have fixed-term maturity and a contractual profit rate. Moreover, it gave the consequences of this argument of Issuing variant of accounting standards to treat these Sukuk.

The dilemma has arisen when the IFRS's compliant firms as listed firms are becoming desirable in Sukuk investment. Accordingly, the willingness of the firm is reduced since they are aware of the accounting conflict and need to be IFRS's compiled since they are imposed to use the IFRS's only. Emphasising on the IFRS9, the radical issues related to the Sukuk are the classification and ECLM application on the Sukuk. The question of how can I as a financial manager classify the Sukuk and apply the ECLM with Sukuk under the IFRS9 to invest is Sukuk and be IFRS's 
complied? The article studied the Jordanian market since Islamic finance is affordable, using a written survey with the listed firms' financial managers in the first stage to identify the problems of Sukuk investment. The next step was semi-structured interviews with Jordanian accounting and Islamic law experts. Finally, a questionnaire was sent to external auditors to provide reasonable assurance of the interviews' results.

The limitations concentrated on the sample and the methodology. The Islamic financial market in Jordan still emergent, that affected the sample by facing difficulties to find a person has the experience in both IFRS's and Islamic accounting. Also, shariah scholars, who are experts in Islamic finance, do not have sufficient information about Islamic accounting as their confession. Accordingly, expanding the sample size ignoring the participator qualification could lead to contain confusing information.

According to the small sample size, the research turned to use qualitative methods. Despite the positive interviews aspect, the challenges that encountered with the meeting compromised the severe limitation of the study. Setting up the meeting with the participators; most of the sample apologized in the first attempt, later many efforts the acceptance to conduct the meeting has been awarded. This situation has complicated the research time table and imposed the researcher to extend the research time plan to keep the methodology flow. Some meetings were time-restricted; therefore, gaining information to suggest other research paths was not in a perfect manner. Additionally, the delay of replying the survey and the questionnaire by the participators

Overcoming the mentioned limitation; this article illustrated how the Sukuk would be classified under IFRS's; on the other hand, obtained that the listed firms in Jordan can apply expected credit loss model on Sukuk investment and it should be by using other prevailed factor than the interest rate and constrained the application as mentioned in the implications.

During the meeting, the researcher realized; the central bank obliges the Islamic banks to apply rules are generally released to the whole banking industry in Jordan. Some of these rules are not satisfied in total with the Islamic finance principles. For example, they are adapting the new issues in IFRS 9 without considering the Islamic finance' differences. Moreover, the classification of all Sukuk as financial assets under the amortisation cost method. This situation opens new paths for discussing the effect of central bank behaviour with the Islamic banks on the development of Islamic finance. Adding more, the effects on the compliance of the Islamic banks with the AAOIFI accounting standards or Islamic accounting standards that issued by some nations.

Since there are organizations like the AAOIFI and other national committees are exerting effort to improve the Islamic financial products and the related accounting treatment. The article suggests conducting researches related to issuing accounting instruction to firms, which are legally imposed to apply the IFRS's or national GAAP, to how to treat the transaction of the Islamic financial product under the adapted standards. In the purpose of encouraging these firms 
to invest in the Islamic finance and avoiding the financial reporting conflicts obstacles, that may lead to spread the acceptance and application of Islamic finance locally and globally.

In sum, the Islamic financial industry is growing at a rapid step internationally. The demand for accounting and reporting requirements that adequately meet the unique Islamic financial instruments is critical to ensuring the stability and sustainable growth of the industry.

This study indicates that there is a need for further studies and discussions on the linkages of Islamic financial instruments to international accounting and reporting requirements in the purpose of increasing the spreading of the Islamic finance in the international financial markets.

It is a hope that IFRS will take into account the features of the Sukuk. That will help meet the desire of Islamic finance to improve the global Islamic financial market as a whole by becoming attractive to international investors. A possible option to resolve this dilemma is to have guidance or opportunities for Islamic financial institutions within the framework of IFRS. To apply these guidelines globally, an Islamic organisation such as AAOIFI can work closely with the International Accounting Standards Board (IASB). 


\section{References}

Accounting and Auditing Organization for Islamic Financial Institutions. Retrieved April 29, 2020a (http://aaoifi.com/announcement/aaoifi-issues-fas-33-investments-in-sukuk-sharesand-similar-instruments-and-fas-34-financial-reporting-for-sukuk-holders/?lang=en).

Accounting and Auditing Organization for Islamic Financial Institutions. (n.d.). Retrieved April 29, 2020, from http://aaoifi.com/announcement/aaoifi-issues-fas-33-investments-in-sukukshares-and-similar-instruments-and-fas-34-financial-reporting-for-sukukholders/?lang=en

Ahmad, A. M. (2018). Accounting and Analytical Aspects Of Reflecting Expenditures in Practice of Companies of Ukraine and Jordan: Comparison, Problems and Improvement Background. Paradigm Of Knowledge, 2(28).

Ahmad, A. U. F. (2016). Regulation, Performance and Future Challenges of Sukuk: The Evidence from Asian Markets'. Advances in Islamic Finance, Marketing, and Management. Emerald Group Publishing Limited, 27-48.

Ahmed, E. R., Islam, M. A., \& Ariffin, K. H. K. (2015). An empirical analysis on legitimacy of sukuk: An insight of malaysian sukuk. Asian Social Science, 11(13), 84.

Ahmed, M. U., Sabirzyanov, R., \& Rosman, R. (2016). A critique on accounting for murabaha contract: A comparative analysis of IFRS and AAOIFI accounting standards. Journal of Islamic Accounting and Business Research, 7(3), 190-201.

Alswaidan, M. W., Daynes, A., \& Pasgas, P. (2017). Understanding and evaluation of risk in Sukuk structures. Journal of Islamic Accounting and Business Research.

Application instruction of IFRS 9- central jordan bank. (n.d.). Retrieved December 24, 2018, from http://www.cbj.gov.jo/DetailsPage/CBJAR/NewsDetails.aspx?ID=227

Bhuiyan, R. A., Rahman, M. P., Saiti, B., \& Ghani, G. M. (2019). Co-movement dynamics between global sukuk and bond markets. International Journal of Emerging Markets.

Biancone, P. P., \& Shakhatreh, M. Z. (2016). Accounting Issues in Sukuk Issuance. International Journal of Islamic Economics and Finance Studies, 2(3), 95-108. https://doi.org/10.12816/0036631

Borhan, N. A., \& Ahmad, N. (2018). Identifying the determinants of Malaysian corporate Sukuk rating. International Journal of Islamic and Middle Eastern Finance and Management.

Fathurahman, H., \& Fitriati, R. (2013). Comparative analysis of return on sukuk and conventional bonds. American Journal of Economics, 3(3), 159-163. 
Gharbi, L. (2016). A critical analysis of the use of fair value by Islamic Financial Institutions. Journal of Islamic Accounting and Business Research.

Godlewski, C. J., Turk-Ariss, R., \& Weill, L. (2013). Sukuk vs. Conventional bonds: A stock market perspective. Journal of Comparative Economics, 41(3), 745-761.

Gomaa, M., Kanagaretnam, K., Mestelman, S., \& Shehata, M. (2018). Testing the Efficacy of Replacing the Incurred Credit Loss Model with the Expected Credit Loss Model. European Accounting Review, 1-26.

Gornjak, M. (2017). Comparison of IAS 39 and IFRS 9: The Analysis of Replacement. International Journal of Management, Knowledge and Learning, 6(1), 115-130.

Hasan, R., Ahmad, A. U. F., \& Parveen, T. (2019). Sukuk risks-a structured review of theoretical research. Journal of Islamic Accounting and Business Research.

Hidayat, S. E. (2013). A comparative analysis between asset based and asset backed sukuk: Which one is more shariah compliant. International SAMANM Journal of Finance and Accounting, 1(2), 24-31.

Hikmany, A.-N. H., \& Oseni, U. A. (2016). Dispute resolution in the Islamic banking industry of Tanzania: Learning from other jurisdictions. International Journal of Islamic and Middle Eastern Finance and Management.

Hossain, M. S., Uddin, M. H., \& Kabir, S. H. (2020). Sukuk and Bond Puzzle: An Analysis with Characteristics Matched Portfolios. Emerging Markets Finance and Trade, 1-26.

Huian, M. C. (2012). Accounting for financial assets and financial liabilities according to IFRS 9. Annals of the Alexandru Ioan Cuza University-Economics, 59(1), 27-47.

IASB. (n.d.). International Financial Reporting Standards (IFRS) and IFRIC Interpretations [LandingPageContent]. Retrieved November 10, 2018, from https://www.iasplus.com/en/standards

Ifrs-in-depth-expected-credit-losses.pdf. (n.d.). Retrieved October 7, 2018, from Www.pwc.com website: https://www.pwc.com/gx/en/audit-services/ifrs/publications/ifrs-9/ifrs-in-depthexpected-credit-losses.pdf

Misman, F. N., \& Ahmad, W. (2011). Loan loss provisions: Evidence from Malaysian Islamic and conventional banks. International Review of Business Research Papers, 7(4), 94-103.

Mohamad, S., \& Hamed, M. (2017). Analytical study of the implications of the adoption of IFRS 9 on the credit and financing policies of Arab banks. Arab Jornal of Science and Research Publishing, 9, 1-26. 
Mohammed, N. F., Mohd Fahmi, F., \& Ahmad, A. E. (2019). The need for Islamic accounting standards: The Malaysian Islamic financial institutions experience. Journal of Islamic Accounting and Business Research, 10(1), 115-133.

Novotny-Farkas, Z. (2016). The interaction of the IFRS 9 expected loss approach with supervisory rules and implications for financial stability. Accounting in Europe, 13(2), 197-227.

Safari, M., \& Ariff, M. (2013). Do Debt Markets Price Șukūk and Conventional Bonds Differently? Journal of King Abdulaziz University: Islamic Economics, 26(2).

Schutte, W. D., Verster, T., Doody, D., Raubenheimer, H., \& Coetzee, P. J. (2020). A proposed benchmark model using a modularised approach to calculate IFRS 9 expected credit loss. Cogent Economics \& Finance, 8(1), 1735681.

Shafii, Z., \& Abdul Rahman, A. R. (2016). Issues on the application of IFRS9 and fair value measurement for Islamic financial instruments. Journal of Islamic Accounting and Business Research, 7(3), 202-214.

Siswantoro, D. (2018). Sharia accounting standard for sukuk (Islamic bond) accounting in Indonesia. Journal of Islamic Accounting and Business Research, 9(3), 434-447.

Smaoui, H., \& Khawaja, M. (2017). The determinants of Sukuk market development. Emerging Markets Finance and Trade, 53(7), 1501-1518. 